\author{
DAVID TORRIJOS-CASTRILLEJO \\ Universidad Eclesiástica San Dámaso, Madrid \\ https://orcid.org/0000-0003-2005-5634
}

\title{
PROCLAIMING THE DIVINE LOGOS TO THE MAN OF THE FUTURE
}

A central service that theology must render is to help in transmitting the Gospel to the world at every moment of history. To this end, it is necessary to make the Gospel known and intelligible to unbelievers. In order to be in a position to carry out this mission in the future, one might review how it is being carried out in the present. For this reason, we will begin by discussing certain deficiencies in the teaching of Christian doctrine in the recent history of Spain in order to reflect on the transmission of the Gospel in the near future. Secondly, we will think about the situation of contemporary man in Europe and his uprooting from his own tradition and the spiritual heritage received from his ancestors. Thirdly, we will briefly see how the neglect of Christian teaching is linked to a certain contempt for the "doctrinal" character of faith. Thus, we will propose Christian teaching as a true proclamation of Jesus Christ and not as something complementary or extrinsic to a supposed "experience" that would be the true heart of Christian life.

\section{THE RECENT SPANISH DEBATE ON CHRISTIAN INTELLECTUALS}

In order to reflect on the growing need for evangelization in our contemporary societies, I shall present an interesting debate that has resonated publicly in my country. I believe that it might be representative of a situation that will persist in different European contexts in the immediate future and will even become more accentuated.

Spain is a European country that experienced early evangelization. Christianity flourished here and bore rich fruits. There is no need to recall its impressive contribution to the evangelization of America, above all, but also of other places in the East, such as the Philippines. Even today, with a number of about 11,000, it 
is probably still the country with the most missionaries in the world ${ }^{1}$. Moreover, we must not forget its important historical contribution to the life of the Church with founders of the stature of St. Dominic of Guzmán, St. Ignatius of Loyola, St. Teresa of Ávila and St. John of the Cross, just to mention the best known. In the 20th century, in spite of so many convulsions in the heart of Catholicism, institutions of great vitality have been founded in Spain, such as Opus Dei or the Neocatechumenal Way. All this does not prevent it from being a country that is undergoing a wide-ranging retreat from Catholicism. Secularization is precipitously imposing itself: Catholicism has ceased to be significant when one interprets and directs one's own life; it has no relevance to the formulation of laws, and has practically disappeared from the public discourse... For this reason, a recent debate about the presence of Catholicism in public life, which attracted some media and public attention, is of special interest. On November 19, 2020, when the encyclical Fratelli tutti was being received, a young professor of philosophy at an important university, the Universidad Autónoma de Madrid, wrote an article in one of the most widely read newspapers in Spain, El Mundo ${ }^{2}$. Diego Garrocho, the professor in question, was surprised by the interest the encyclical had aroused: politicians who oppose the Church's magisterium on homosexuality, divorce, abortion, euthanasia, the right of parents to choose their children's school, etc., nevertheless celebrated the encyclical; they saw in it a confirmation of their (socialist) economic and immigration policies. Of course, the astonishment provoked by the encyclical indicates that they are not very familiar with the great tradition of the Social Doctrine of the Church. In any case, their declarations were rather an artifice to win over certain Catholics while ridiculing their political enemies, who defend the family and the Church more than they do, but are in favor, for example, of more restrictive immigration laws.

The above lines were only intended to contextualize Garrocho's article. He was not interested in talking about the reception of Fratelli tutti or the Spanish political factions. His article asked "Where are the Christian intellectuals?" According to him, "in a scenario marked by the cultural war in which each Identitarianism exhibits its representatives and activists, specifically Christian thought is entirely absent". Consequently, all positions are represented in the public debate, except the Christian one: "[...] there is the cultural left, Talmudic Marxism, social democracy, left-wing populism, right-wing populism, erudite liberalism, audiobook liberalism, ecologists, the right-wing left, Queer Theory, aestheticizing conservatives, revolutionary late adolescence, the extreme center, those with one party card, those with the other card... And there is, of course, excessive and bandwagon Catholicism.

1 Obras Misionales Pontificias en España, Memoria de actividades 2019, Madrid: Dehon 2020, s. 20; Conferencia Episcopal Española, Memoria Anual de Actividades de la Iglesia Católica en España año 2019, Madrid: EDICE 2021, p. 16; p. 21.

2 D. Garrocho, ¿Dónde están los cristianos?, El Mundo, https://www.elmundo.es/opinion/ columnistas/2020/11/16/5fb28a36fc6c83e7528b460b.html [access: 13 XI 2020]. 
They are all, absolutely all in an exercise of symphonic tuning, all except the Christian intelligentsia".

Garrocho recalls the great Christian intellectuals of the 20th century who have managed to be present in the public debate, nominally mentioning J. Ratzinger, H.U. von Balthasar and R. Brague. However, according to him, personalities of this caliber, who really present the word of Christ as being able to enlighten people's lives, do not appear in the most popular forums today.

Garrocho's article was well received and some discussion followed its appearance, especially because some Catholics claimed the existence of many people of great cultural stature worthy of being called "Christian intellectuals". This type of response prompted another article of with repercussions just as profound as Garrocho's, also signed by a university professor of philosophy, Miguel Ángel Quintana $\mathrm{Paz}^{3}$. This article appeared on an online medium, The Objective. He stressed that, despite the superficial criticisms against Garrocho, he never pretended to deny the existence of Christian intellectuals. He only lamented their absence in the public forum: yes, there are Christian intellectuals, but their voice is not heard and this should lead us to reflect. Of course, it is not possible to complain about a lack of resources for spreading the Gospel or to moan because the media silence them, since in Spain the Catholic Church has one of the radio stations with the widest audience in the country (COPE) and even a television channel. More important, there is a wide network of educational centers with a Catholic identity: schools, secondary schools and several Catholic universities. To get an idea of the importance of the Catholic education in Spain, let us consider that, according to the Annual Report of Activities of the Catholic Church in Spain, schools with Catholic identity have $1,523,777$ students, compared to a total of $8,237,006$ children in the school ${ }^{4}$. It constitutes a very significant part, especially if we take into account that $1,814,140$ students attend the subject of Catholic Religion in the state school ${ }^{5}$. But the school is not the only resource of the Catholic Church in Spain. Quintana Paz insists on other ones: "Such a Church has still today in Spain a network of [...] publishing houses, associations, organizations, institutes, congregations, buildings, museums..., enough to not depend on whether or not 'others' grant you the word.

3 M.Á. Quintana Paz, ¿Dónde están (escondidos) los intelectuales cristianos?, https://theobjective.com/elsubjetivo/donde-estan-escondidos-los-intelectuales-cristianos [access: 19 XI 2020].

4 See: Conferencia Episcopal Española, Memoria Anual de Actividades de la Iglesia Católica en España año 2019, p. 28. The number has slightly increased, since there were 1,521,196 students in 2018: see Conferencia Episcopal Española, Memoria Anual de Actividades de la Iglesia Católica en España año 2018, Madrid: EDICE 2019, p. 53. For the total of students in Spain, see Ministerio de Educación y Formación Profesional, Datos y cifras. Curso escolar 2019/2020, Madrid: Secretaría General Técnica 2019, p. 3.

5 See: Conferencia Episcopal Española, Memoria Anual de Actividades de la Iglesia Católica en España año 2019, p. 30. 
Are these enormous resources really being used in the optimal way that would allow the Catholics to go well equipped to the intellectual war?"

According to him, these "talents" are being squandered in an "unforgivable" way. With very few exceptions, these resources are not being used to disseminate "the immense artistic, literary and musical legacy of Christianity". Therefore, he makes some suggestions for Catholic television: "Why not explain, in audiovisual format, the ideas of (to recall only those cited here) Ratzinger, Brague, Girard?"

Even more disappointing for Quintana Paz is the result of long years of teaching religion in school: many of the boys who have passed through these courses barely know a couple of essential things about Christianity. They are not able to enumerate the "theological virtues" nor have they heard of the great Ecumenical Councils or the Fathers of the Church. As for the Catholic universities (sixteen in all!, plus two ecclesiastical faculties of theology), in spite of having more than qualified personnel, such intellectuals do not seem to be able to introduce themselves into the social debates, to generate discussions with repercussions in public life, to debate with dissenting positions... While the Christian identity of the Catholic universities is much clearer than that of the schools, nevertheless they do not manage to transmit the message to the general public.

After these two articles, a whole torrent of literature began to flow, generating a wide discussion. For example, Fernando de Haro, who speaks in the above-mentioned Catholic radio station, complained that insisting too much on the transmission of Christian doctrinal elements could turn Christianity into "a museum with magnificent pieces" or a mere "legacy" 6 . Similarly, Torralba insisted on Guardini's idea, according to which Christianity is not a doctrine but a person, Jesus of Nazareth $^{7}$. Christianity would be related to the event of grace that happens in people even when they are not intellectuals.

Another answer that has been repeated on several occasions was presented in an article by Juan Arana, a philosopher of recognized prestige in our country ${ }^{8}$. Although he too laments the scarce importance of doctrinal content in contemporary catechesis, he takes a different point of view. On the one hand, he believes that there is a great lack of intellectuals (not only Christian intellectuals) in public life, but on the other hand he finds the expression "Christian intellectual" unfortunate. An intellectual must first and foremost be an intellectual, but the human sciences are truly scientific because they conform to facts and reason. Therefore, it is not beneficial for Christianity if the personal positions of an intellectual or the opinions of a certain school are presented as "officially" Christian, because this could

6 F. de Haro, Sobre la aportación de los cristianos, https://paginasdigital.es/sobre-la-aportacion-de-los-cristianos/ [access: 23 XI 2020].

7 J.M. Torralba, ¿Dónde estamos los cristianos?, https://www.elespanol.com/opinion/tribunas/20201126/cristianos/538566140_12.html [access: 26 XI 2020].

8 J. Arana, ¿Hacen falta más 'intelectuales cristianos'?, https://www.aceprensa.com/cultura/ intelectuales/hacen-falta-mas-intelectuales-cristianos/ [access: 3 XII 2020]. 
endanger the very deposit of faith and also the freedom of scientific research. In connection with this idea, the controversy about "Christian philosophy" has been recalled in the conversations provoked by these articles, and some have even quoted the words of Heidegger, for whom this expression was as unintelligible as that of a "wooden iron" ". It would be necessary, therefore, to promote intellectual education but not to mix the human sciences with theology if we do not want to damage the former and the latter.

\section{EVANGELIZING THE NEW BARBARIANS}

This debate about the present need for a Christian intellectuality forces us to think about the transmission of Christian wisdom to the man of tomorrow. Who is the man of tomorrow? I think he can be described more or less as a "new barbarian". Since we began these pages with a Spanish debate, let us now also use an expression used by a well-known Spanish philosopher, Ortega y Gasset, in a somewhat challenging way. As he warned almost a century ago, contemporary man is sinking into a new form of barbarism. What is the nature of barbarism? For Ortega it is "the absence of standards to which appeal can be made"10. The barbarian ceases to count on others and gives way to "direct action". Barbarism consists in an exercise of the will ignoring the others. According to Ortega, we are surrounded by barbarians: "This type which at present is to be found everywhere, and everywhere imposes his own spiritual barbarism, is, in fact, the spoiled child of human history. The spoiled child is the heir who behaves exclusively as a mere heir. In this case the inheritance is civilization - with its conveniences, its security; in a word, with all its advantages" 11 .

It should not be thought that this qualifier is a disdain for the intellectual capacity of those who are called barbarians, since for Ortega, "the prototype of the $[\ldots]$ modern barbarian" is the scientist $t^{12}$. The specialization of science achieves the settlement of this new form of barbarism that dominates in a certain field but does not worry about its effective ignorance in other fields. The specialist also takes for granted the civilization in which he is installed, just as he takes for granted, without question, the presuppositions of his own knowledge.

9 M. Heidegger, Phänomenologie und Theologie, in Gesamtausgabe, vol. 9, Frankfurt am Main: Vittorio Klostermann 1976, p. 66.

10 J. Ortega y Gasset, The Revolt of the Masses, New York: Norton 1957, p. 72.

11 J. Ortega y Gasset, The Revolt of the Masses, p. 98.

12 J. Ortega y Gasset, The Revolt of the Masses, p. 109. 
I believe that Ortega's diagnosis is still very valid and that it is even more so in terms of understanding man today. Our contemporaries are barbarians. Mass tourism is perhaps one of the best expressions of this new barbarism. Recently, people who took selfies in the Auschwitz camp caused quite a stir. To me, selfies in a Roman circus (a place of martyrdom!) or on the main altar of a cathedral, where tourists wander curiously around the presbytery as if they were in a theme park, seem equally barbaric. Just the spectacle of half-naked bodies running through the elegant streets of ancient European cities is barbaric. For them, basic cultural instances are devoid of any sense: clothes, places, behavior, religion, history... Here is the new barbarian, with no father, mother or ancestry: no fatherland, no family, no God. Contemporary young people give up raising a family to work for others in a business that does not belong to them, often in precarious conditions, many times forced to leave their homeland or, in any case, without more feeling of attachment than to any other place.

Needless to say, we are facing an enlightened barbarism. Our contemporaries are highly qualified people in their small field of work. Nevertheless, they have lost the sapiential capacity to apply intelligence to their own lives. This is a very common monster of our times: people who are capable of razor-sharp intelligence in their professional fields but absolutely incapable of grasping the slightest subtleties in moral reasoning. In fact, reasoning and truth do not seem to count for anything in the search for the meaning of one's life. Feeling is enough. If anything, another "expert" is entrusted with the "management" of emotions or time. A coach or a psychologist who, instead of a sapiential intelligence, makes use of the same technical mentality to deal with moral problems.

The contemporary barbarian is a kind of Robinson. He is not a "savage", but a man who has landed in a world foreign to him. The supposed "savage" knows full well where he is. He knows his world and is surrounded by a universe full of meaning. He has myths and traditions to orient himself in life. The contemporary man, on the contrary, is a man who has come from nowhere and has no goal ${ }^{13}$. He finds himself surrounded by a world he does not understand, a world without any meaning and, at the end of the day, he has nothing to do there. In this sense, he is more "savage" than any preceding barbarian. Despite all his (eventual) encyclopedic knowledge, he ignores the meaning of life, the value of the family; he is not capable of thinking about birth or death. Procreation and sexuality are devoid of meaning for

13 The several descriptions of contemporary man made by Hadjadj are illuminating. See for example: “[...] l'individualité est présentée comme un point de départ, l'individu étant arraché à ses appartenances naturelles et historiques, il devient trop faible pour résister aux sirènes technoéconomiques qui lui proposent la réussite et le bien-être via le quantified-self, une vie disloquée en une série de fonctions séparables et améliorables, en une somme de paramètres que résoudra l'algorithme du bonheur", F. Hadjajd, Dernières nouvelles de l'homme (et de la femme aussi), Paris: Tallandier 2017, pdf, https://www.decitre.fr/ebooks/dernieres-nouvelles-de-1-homme-9791021029842_9791021029842_1. html [access: 15 X 2021]. 
him. He is probably the poorest of mankind. Illiterate people of antiquity or Middle Ages were much more civilized than him, but he feels himself superior to them.

Barbarism, according to Ortega, has a nihilist component ${ }^{14}$. Its purpose is destruction. It is an impulse that we encounter every day, promoted even by great world powers through the "woke culture". Behind all this "moralistic" desire to introduce everyone to a global ethic that would respect a set of universal values, there is a deep nihilism. It is a nihilism that destroys traditions, cultures and the characteristic features of peoples. This has been pointed out by Rémi Brague: "There is such a thing as historical barbarism, which is a will to forget, to weigh the anchors, to cast one's moorings in the past. Unfortunately, attempts at such an artificial forgetfulness crop up in our present days. In my country, reforms in the educational system give evidence of a deliberate intention to get rid of whatever constituted the reference points of our identity. France is not the only country that is menaced" 15 .

It is a truly destructive movement that threatens to do away with all the parameters that help man to orient himself in life, among which the Christian faith stands out. However, this nihilism of contemporary man ends up provoking great anxiety and emptiness, increasingly observable in de-Christianized societies - with the dissolution of the family, which is the bastion of meaning and tradition for people, depressive processes, psychic disorders, suicide, underhand or overt forms of violence and other scourges multiply.

I believe that it is from the depths of this growing nihilism that the cry for help is born, asking for meaning from the Christian tradition. That is the hidden claim of this debate on "Christian intellectuals". Rémi Brague has said that, whether we like it or not, we are approaching a new Middle Ages ${ }^{16}$. Just as in the first Middle Ages, the barbarians threaten to destroy civilization and, just as then, it could be that Christianity will also preserve the remnants that strengthened the culture now threatened by ruin. Whoever loses faith, ends up losing reason and common sense, as Chesterton has insisted in many ways. No wonder that it would be the believers who safeguard thought, in the truest sense of the word.

Brague does not take such a unilaterally negative view of "barbarism" as Ortega does. He looks at the original meaning of barbarism as the inability to communicate ${ }^{17}$. In contrast, civilization consists in a kind of conversation. It is about understanding between people. In this sense, not all "barbarians" have behaved destructively, since many among those who invaded the Roman Empire sought to

14 See: Ortega y Gasset, The Revolt of the Masses, p. 106.

15 R. Brague, Curing Mad Truths. Medieval Wisdom for the Modern Age, Notre Dame: Notre Dame UP 2019, p. 109.

16 See: R. Brague, Le propre de l'homme. Sur une légitimité menacée, Paris: Flammarion 2013, p. 248.

17 See: Brague, Curing Mad Truths, p. 103. 
incorporate themselves in its community ${ }^{18}$. Instead, true barbarism is a refusal to communicate and that means a deliberate blocking of "continuity"19. Such a blockage is a refusal to have a common heritage to transmit to others.

What Brague intends to defend is not a kind of "conservatism". As I once wrote, "tradition does not turn its followers into servants of an outdated and sterile procedure, but provides an orientation that enriches their actions and allows them to walk further than those who negligently and arrogantly pretend to start their own journey without the help of recognized masters. To follow tradition, then, it is not necessary to be 'conservative'. If it were necessary to conserve it, tradition would be fragile. But it is a sign of its freshness that it is tradition that preserves us, makes us who we are and therefore allows us to be creative. Tradition is not preserved, it is transmitted. Far from being fragile, it is fruitful" ${ }^{\prime 20}$. In a similar sense, Brague states that "tradition is living transmission. We can carry on because the past carries us forth. The past has made us"

For these reasons, strengthening civilization means taking care of the conversation among the members of society, and this conversation must also include the members of the community who are no longer with us. It is a conversation that must continue to be practiced even with the dead, as Chesterton said, in order to make the dialogue truly realistic ${ }^{22}$. To leave out the dead would be an authoritarianism that would be inconsistent with the democratic attitude that contemporary man claims to have. A true integrative attitude leads to the respect of tradition.

In short, in de-Christianized societies such as those in Europe, it is necessary to help the barbarians to recognize who they are. They live like "Robinsons", but in reality they are more similar to the Segismundo of the superb play La vida es sueño (Life is a dream) by Calderón de la Barca - also Spanish - although this drama takes place in Poland. Segismundo is a crown prince who lives a life of imprisonment and is deceived about his condition by his own father, because a false omen foretold that he would be a heartless king. To prevent him from reigning and harming the people, his father keeps him in a dungeon but, finally, he discovers that he is king and, with the help of the people, he reaches the throne and his clement behavior disproves the untruthful oracle. It is an inversion of the tragedy of Oedipus. The "tragic recognition" (anagnorisis) does not reveal here a hidden situation of unhappiness that ruins somebody's life. Inspired by the Christian event, Calderón starts

18 See: Brague, Curing Mad Truths, pp. 106-107.

19 See: Brague, Curing Mad Truths, p. 107.

20 D. Torrijos-Castrillejo, Historia de la filosofía moderna y contemporánea, Madrid: Ediciones Universidad San Dámaso 2017, p. 6.

21 Brague, Curing Mad Truths, p. 109.

22 "Tradition means giving votes to the most obscure of all classes, our ancestors. It is the democracy of the dead. Tradition refuses to submit to the small and arrogant oligarchy of those who merely happen to be walking about", G.K. Chesterton, Orthodoxy, London: The Bodley Head 1957, p. 70. 
from misery and the discovery of one's identity opens a future of blessedness. In fact, there is an "auto sacramental" (a Spanish religious drama) identically entitled by the same author, in which he identifies the prisoner with a soul led from the darkness of sin by the power of Christ.

Agnosce, o Christiane, dignitatem tuam ${ }^{23}$. The new barbarian must recognize who he is. The barbarian thinks he is a foreigner but in reality he is in his homeland. He thinks he is an exile but he is at home. His home is the Church and Christianity. There he will find the happiness he longs for and which he unsuccessfully seeks in yoga or reiki. He must recognize himself as a child of his own tradition and of the religion of his ancestors. The heart of the children must turn to the heart of the parents and so the heart of the parents will turn to the heart of the children (Mal 4,6). Chesterton had also made this suggestion at the beginning of his The Everlasting Man: contemporary man goes about looking for something big, like one who leaves his home in search of giants and, when he wanders away, then realizes that his home was set up on a huge giant ${ }^{24}$. Thus, Chesterton says there, if the gospel were presented as belonging to an arcane Oriental culture, it might perhaps awaken all the appeal it really has. It would not be that vulgar thing which one despises as a useless antiquity that hinders the growth of our people, but would be full of the charm of novelty.

Considering the immense ignorance of Christianity among the younger generations in countries with ancient Catholic roots, it seems that the time to present Christianity as something novel and alternative has come. In fact, we will not have to make an extreme effort to present it as something new, because in fact it is already new to them.

\section{PROCLAIMING THE LOGOS OF GOD}

In Acts 4,31 - which serves as the title of this epigraph - as in many other places in Scripture, the Gospel message to be transmitted by the apostles is called the logos of God. We usually translate this term as "word", but it is no accident that it also designates reasoning and reason itself. Although the "Hellenization" of Christianity is presented again and again as a damage to it, the historical evidence confirms that Christianity was born in an already Hellenized and not "purely" Jewish environment. For the believer, this fact is not incidental, but it is wanted by God. Likewise, it is wanted by God that faith be a kind of rational acceptance of Him.

23 Leo Magnus, Sermo, 21, ch. 3, PL 54, 192C.

24 See: G.K. Chesterton, The Everlasting Man, London: Hodder \& Stoughton 1927, p. 9. 
Greece was not indispensable for this because the Jews were already behaving rationally even before their contact with Greek philosophy.

It is not my purpose in these brief pages to dwell on the question of the relationship between rational thought and faith. However, once we have reached the more propositional part of my article, I would like to make some reflections on the importance of rationality linked to theological reflection and the transmission of faith.

It is evident that the lack of knowledge of the Catholic faith in countries of ancient Christian tradition has been due in large part to the crisis of faith that the Church experienced in the last century. Many of the ministers who should have proclaimed the word of God stopped doing so and dedicated themselves to transmitting other doctrines or to promoting certain social or philanthropic activities. This has been a remarkable obstacle in the transmission of the faith precisely at a time of great complexity, during which Christians needed more nourishment than ever for their souls. But I believe that not only those who have opposed the traditional doctrine of the Church in a more accentuated way are the unique obstacle for its transmission. Among other Catholics too, who are better intentioned and more faithful to ecclesiastical authority, has a climate of anti-intellectualism been accentuated, which continues to persist even today and does not help evangelization very much.

Even if this contemporary view is not mere fideism, because it is not a fundamentalism that avoids any kind of rational discourse outside the faith, it does not favor the believer's own reasoning. It is rather a position contrary to the "doctrinal" character of faith. An anecdote narrated by Juan Arana in the article referred to above could be illustrative of this behavior: "[...] a colleague of mine, a university professor of philosophy, offered to give classes in a confirmation catechesis. Very soon the person in charge of the catechesis admonished him: 'But, what do they tell me you are teaching the kids?' 'Well..., the mysteries of the faith: the Trinity, the Incarnation, the Redemption...' 'No, no, what nonsense! What you have to teach them is that Jesus loves them'. 'But, Father, do you realize that these kids already know how to solve integrals and study molecular biology?' It was impossible that he come to his senses. My friend had to resign from his task".

This could simply be an anecdote about the superficiality of a certain priest or a certain Christian community, but I fear that this problem is rooted in some tendencies present in the formation of the priests and in theology itself. There has been an inclination to think of faith as the source of its own rationality, which would spring from an experience of encounter with Jesus Christ that, at the end of the day, would be incommunicable. Only after having this incommunicable experience would it be possible, if at all, to develop a thought inspired by it. The widespread insistence on apophatism and the ineffability of God comes to help this thesis. In short, any discourse that speaks of Christianity or faith would be an approximation that would never sufficiently enunciate the pristine experience of the encounter with Jesus Christ. 
There is no doubt that the essence of Christianity is not a teaching apart from the reality of God intervening in history, and in this sense Guardini was absolutely right on the mark ${ }^{25}$. What is crucial is that God acts in history and does so in a particular way, incarnating himself in Jesus Christ and so on. However, the Christian fact in the present moment of history really reaches people through Christian proclamation. For Christians have always taken it for granted that words and reason are not incapable of communicating the facts but that they bring people into a relationship with the facts. Rational developments are not an obstacle between us and the facts, even if every human reconstruction of the facts always suffers from a certain deficiency. Maybe, our arguments and our words can be improved, but if they are true, then they already put us in contact with reality. They do not put us in contact with a reconstruction of reality, but with reality itself.

This is why I would like to insist here that "Christian doctrine" is not a secondary part of the transmission of faith. Faith is not an ineffable experience, but consists precisely in accepting the witness that has been communicated by another person. There is no possibility of an encounter with Jesus Christ apart from the acceptance of the testimony of his witnesses. Therefore, this testimony must be adequately articulated in words intelligible to everyone, not only to those who have already participated in the "experience" that we want to provoke in them. We must not forget that the teaching of the faith, theology, that is, "speaking of God" or "thinking about God" is, in substance, that proclamation of the word of God that the apostles made in order to make known the acts of God to those who did not yet have faith. Faith is the adherence of man to God's revelation ${ }^{26}$. But this means that revelation can be known and communicated to those who have not yet received it. If the intelligibility of revelation were only accessible to those who have already received revelation, we would be falling into a kind of petitio principii. Revelation per se is intelligible in itself and can be transmitted in words that everyone can understand. That is why the miracle of Pentecost was a miracle of communication. The understanding of the apostolic proclamation does not spring from faith (which those who hear it do not have) but is the presupposition of faith. If the message is not understood, it is as if it were not heard: in French, the verb to hear (entendre) comes from the Latin verb to understand (intelligere). "And how can they believe if they have never heard?" (Rom 10:14).

Therefore, Christian doctrine cannot have a secret rationality that is the exclusive patrimony of those who have faith, but it can be explained in a way that can be understood even by those who do not possess it. Moreover, the very explanation of faith is already a form of proclamation. Or, if you will, the proclamation must consist in this kind of explanation. Faith involves accepting this announcement as

25 See: R. Guardini, Das Wesen des Christentums, Würzburg: Werkbund 1938.

26 "Faith is a personal adherence of the whole man to God who reveals himself", John Paul II, Catechism of the Catholic Church, §176, London: Burns \& Oates 2006, p. 44. 
true, and this happens by the grace of God. A grace that, by the way, is not experienced: we believe that no one confesses the faith except by the work of grace, for so it has been revealed to us (e.g., 1 Cor 12:3). However, the heretic can erroneously think that his faith is a gift of the Holy Spirit while, in reality, he does so only by human conviction, as St. Thomas teaches (S.Th. II-II, q. 5, a. 3, co.). That is possible because the grace as such is not properly experienced so that we should recognize its works by their results $(\mathrm{Mt} 7,20)$ and judge the spirits according to the communicable teaching of the Church (1 Jn 4,1).

Properly speaking, God is not experienced in the same way as the content of our knowledge is: we have experiences of our psychic acts and physical things that surround us, but the only adequate experience of God would be to see Him face to face. Therefore, in the final analysis, the ultimate criterion for discerning a supposed "experience of God" is the judgment of the Church, since no human opinion, emotion or work is above the faith as taught by the magisterium of the Church. This is corroborated by someone as "experienced" in divine motions as St. John of the $\mathrm{Cross}^{27}$.

Consequently, we cannot fall into a continuous lowering of Christian doctrine as if this were not harmful to the faith. It is not a good pretext to appeal to people's lack of culture, especially because in countries with an ancient Christian tradition, the "new barbarians" are people who are increasingly capable of assimilating knowledge, as we have already mentioned. Even if this were so, the teaching of the minimum requirements of the doctrine of the faith is an integral part of Christian proclamation and it is necessary in order to satisfactorily accept the faith.

I have heard some expert in theology saying that nowadays the teachings of St. Augustine or St. Thomas are not intelligible anymore for "the people". This is perhaps a pretext to stop explaining the philosophy and theology developed by these holy doctors. However, I believe that our mission as transmitters of the Gospel and especially as theologians lies precisely in clarifying their teaching in such a way that our contemporaries can understand and appreciate it. If someone does not understand what "habitual grace" or "divine person" means, then we will have to teach it. We cannot pass over such central teachings because the concepts seem too difficult for our listeners! Divine Providence wanted the term "hypostasis" to be chosen by the Fathers, after much effort, to express the faith of the fishermen of Galilee. I cannot understand what sort of Christian "experience" could be originated without accepting Jesus Christ as a divine person, because there is no true faith in Jesus as Savior if he is not really an incarnate Divine person.

It is part of the transmission of faith to show precisely how it should be confessed. For this reason, it must include the explanation of the Symbol of the faith in as much detail as possible. Precisely therein lies the richness of the Church,

27 See: San Juan de la Cruz, "Subida al Monte Carmelo", II, 20, in: Obras completas, Madrid: BAC 2005, p. 356-359. 
whose spiritual patrimony is not a mere collection of intellectual relics that only a privileged few can enjoy. This fortune belongs to the simplest Christians, and those of us in the Church, whose mission is to teach the doctrine of faith, have no right to keep it to ourselves. The teachings of the Fathers of the Church and of the holy Doctors can and must be transmitted in an adequate way even to people of humbler intelligence.

All this can form part of a new conception of "Christian initiation" in which people are taught to enjoy the treasure of the Christian life as a whole. Something analogous should happen with other facets of the life of the Church, such as Christian art, for example. It is possible that most people today are only familiar with pop music. However, it is possible to assist such a person, with due time and dedication, to appreciate for instance Bach. Similarly, there is an colossal grandeur in Christian art or liturgy which beauty and truth remains to be shown and explained. E.g., everyone should be able to assimilate on his own the adoration implicit in incensing the Blessed Sacrament. The solution would not be to replace incensation with an applause or something like this, on the pretext that the meaning of incense is no longer understood.

Undoubtedly, verbal explanations will be of great help but, at the same time, the manifold forms of art (music, sculpture, poetry...) have the virtue of helping in the understanding of the word. Christian proclamation is vertiginous and exciting. If it does not move us, it is because we have not thought about it enough. The artist knows how to use the magic of the senses to move the intelligence to grasp the greatness, the misery, the happiness and the guilt. This is where not only the traditional fine arts come in, but also rhetoric and new forms of communication, such as the audiovisual media and social networks, as well as new forms of art including, of course, cinema, as well as series for the small screen and even others less explored such as video games ${ }^{28}$.

In this hyper-emotionalized culture we tend to think that emotion is everything. But this is not so. What is central to faith is not the emotion it produces ${ }^{29}$. Having

${ }^{28}$ One of the reviewers commented that video games could enclose the catechumen in the inner world of imagination and sensorial experiences and make him even less able to open his life to the Gospel. I would remark here that, in any case, video games as well as more accepted instruments as books are only tools that are intended to lead people to a real encounter with Christ in the Church through the oral teaching, the ecclesial communion and the sacraments. A video game could be more problematic because the logic of playing itself is a logic of control. But a video game can renunciate to put the economic interest as its main purpose and, accordingly, instead of be high stimulating and addictive, it could be able to develop many contemplative dimensions. Some artists are working in this new way of making "slow" video games: see for instance T. Fullerton, Walden, a game: Reflection, in: M.T. Payne and N. Huntemann (eds.), How to Play Video Games, New York: New York University Press, 2019, p. 335.

29 This is one of the great risks of our time: to intend only or principally an emotional effect when we design our music, catechesis and liturgy. Contemporary emotionalism is a consequence of individualism and an enemy of the Gospel in itself. To pretend to communicate the Gospel by 
this in mind, however, if the Christian message is not impressive, a part of the communication is failing. Classical rhetoric taught us to use emotions to support (not to replace) the truth. Therefore, if one is told about the Katyn massacre, for example, one will experience revulsion and indignation. But if Andrzej Wajda paints those events in front of our eyes, that truth will be indelibly stamped in our souls. Similarly, I think that few recent pastoral initiatives have done such a great service to the transmission of the Gospel throughout the world as the film The Passion of the Christ by Mel Gibson. In this same line, we have a long way to go and theologians will have to walk in the future much more hand in hand with all the experts in communication to transmit in the Christian doctrine very different ways. But, of course, those experts should be true Christians that put the Gospel before other secular interests. In other case, this collaboration would be very difficult.

\section{CONCLUSIONS}

The path we have walked started from a Spanish debate to thought on how theology should face its mission for the future in societies that have ancient Christian roots but are in an advanced process of secularization. The Spanish debate on Christian intellectuals has shown the ineffectiveness of the resources that the Church actually has in order to evangelize, which are spent on other objectives and do not achieve their main mission: to make the word of God known so that it can be embraced. In fact, the word of God does not resonate in the ears of many people in Spain and this means that a deficient evangelization is being carried out.

The addressee of this proclamation is a subject who has lost his roots; he is a "new barbarian". The cause of this barbarism is not a lack of education but perhaps an excess of a misdirected education. Bad education is worse than no education at all. An education that positively excludes the sapiential dimension of life should be described as a bad one. The new barbarian has lost the ability to look at his life with sapiential eyes and is being increasingly anesthetized to understand its meaning. Nevertheless, the prevailing nihilism ravages individuals and, sooner or later, the search for real, authentic and consistent meaning emerges. This is why theology has the mission of enunciating the Christian message without postponing the announcement to an ineffable "experience". In the post-apostolic Church there can be no contact with Jesus Christ, that is, no real "encounter" with Him, if it is not through the very proclamation of Jesus Christ. This presupposes that Christian

producing emotional music or performances is similar to trying to put out a fire with gasoline. The Gospel is a matter of truth not a matter of feelings. 
doctrine be taught and explained. It is necessary to make not only the Gospel known, but also the Christian doctrine as it was announced in detail by the Councils, the Fathers and Doctors of the Church. Even if theology presupposes faith and this includes a divine intervention by grace, the message itself can be formulated in human words and these words are not something secondary to the transmission of the faith, but an integral part of proclamation and catechesis.

Theologians, like so many other academics, must help to popularize the teachings of the faith, with the help of artists and communicators. This teaching is supposed to reach all Christian people and should even be proposed to non-Christians. We cannot reduce Christian wisdom and deprive it of all its richness. The knowledge gained by theology is not an erudite patrimony on the margins of an alleged ineffable "experience of Christ". On the contrary, the concrete way of entering into a relationship with Christ today is to embrace the faith, that is, to accept as true what is announced about Christ by his witnesses. If theology has developed a complex way of thinking, it did so as a way of helping the precariousness of human intelligence when it comes to receive Christ, through the acceptance of the testimony of his disciples: the theological teachings are a help for the evangelization, not an obstacle in its way! If we lower the doctrine, we would reduce the conditions of acceptance of the very message. Since to assimilate Christian faith is not to assimilate some "ideas" but to touch the very reality of God and His Son, then to prevent the teaching of the doctrine means to hinder the very encounter with God. For this reason, theologians will have to work in the future with experts in communication so that Christian doctrine, in all its richness, can be known and the message of our Savior embraced by all men.

\section{GŁOSZENIE BOSKIEGO LOGOSU \\ CZŁOWIEKOWI PRZYSZŁOŚCI}

Streszczenie

Niniejszy artykuł opisuje współpracę teologii w nowej ewangelizacji w społeczeństwach tradycyjnie chrześcijańskich, które przeżywają zaawansowany proces sekularyzacji. Rozpoczyna się on od przykładu Hiszpanii, gdzie niedawna debata na temat wpływu chrześcijańskich intelektualistów na życie społeczne wskazuje na nieskuteczność środków kościelnych w przekazywaniu bogatego katolickiego dziedzictwa doktrynalnego. Następnie autor zajmuje się szczególną wrażliwością współczesnego człowieka, bliską również człowiekowi z najbliższej przyszłości: jest on podmiotem pozbawionym korzeni, który nie wierzy, że życie ma jakikolwiek sens, jest głęboko naznaczony emotywizmem i przywiązuje niewielką wagę do prawdy. Teologia jutra nie może podsycać tego emotywizmu, ale musi być na swój sposób proaktywna. Głoszenie Ewangelii nie różni się od wykładni doktryny Kościoła. Oderwanie ewangelizacji od chrześcijańskiej doktryny nie może pomóc 
w spotkaniu z Chrystusem. Aby odnieść sukces w przekazywaniu tej doktryny i by uczynić ją sugestywną, teologowie powinni współpracować z ekspertami w dziedzinie komunikacji.

Słow a kluc zow e: nowa ewangelizacja, doktryna chrześcijańska, komunikacja, wiara i rozum, spotkanie.

\title{
PROCLAIMING THE DIVINE LOGOS \\ TO THE MAN OF THE FUTURE
}

\begin{abstract}
Summary
This paper studies the cooperation of theology in the new evangelization in societies of ancient Christian tradition which are suffering an advanced process of secularization. It begins with Spain, where a recent debate on the influence of Christian intellectuals on social life suggests the ineffectiveness of ecclesiastical resources in transmitting the rich Catholic doctrinal heritage. The author then deals with the idiosyncrasy of contemporary man, which lies near one of the immediate future's of man: an uprooted subject who does not believe that life has any meaning, deeply marked by emotivism and attaches little significance to truth. The theology of tomorrow cannot feed this emotivism but must be proactive in its own way. The proclamation of the Gospel is not different from the exposition of the Church's doctrine. To detach evangelization from the teaching of Christian doctrine cannot help the experience with Christ. In order to succeed in transmitting this doctrine by making it suggestive, theologians should work together with experts in communication.
\end{abstract}

Keyw ords: new evangelization, Christian doctrine, communication, faith and reason, encounter.

\section{VERKÜNDIGUNG DES GÖTTLICHEN LOGOS DEM MENSCHEN DER ZUKUNFT}

\section{Zusammenfassung}

Dieser Artikel beschreibt die Mitarbeit der Theologie an der Neuevangelisierung in Gesellschaften der christlichen Tradition, die einen fortgeschrittenen Prozess der Säkularisierung erleben. Er beginnt mit dem Beispiel Spaniens, wo die jüngste Debatte über den Einfluss christlicher Intellektueller auf das gesellschaftliche Leben die Unwirksamkeit kirchlicher Mittel bei der Weitergabe des reichen katholischen Erbes beweist. Der Autor spricht dann die eigene Empfindlichkeit des modernen Menschen an, die der des Menschen der nahen Zukunft nahekommt: Er ist ein Subjekt ohne geistige Wurzeln, das nicht glaubt, dass das Leben einen Sinn hat, zutiefst von Emotivismus geprägt ist und der Wahrheit wenig Bedeutung beimisst. Die Theologie von morgen darf diesen Emotivismus nicht anheizen, sondern muss auf ihre eigene Weise proaktiv sein. Die Verkündigung des Evangeliums ist nichts anderes als die Auslegung der kirchlichen Lehre. Die Trennung von Evangelisation 
und christlicher Lehre kann die Begegnung mit Christus nicht fördern. Damit es gelingt, diese Lehre zu vermitteln und anschaulich zu machen, sollten Theologen mit Kommunikationsexperten zusammenarbeiten.

Schlüsselw örter: Neuevangelisierung, christliche Lehre, Kommunikation, Glaube und Vernunft, Begegnung.

\section{BIBLIOGRAPHY}

Arana J., ¿Hacen falta más 'intelectuales cristianos’?, https://www.aceprensa.com/cultura/ intelectuales/hacen-falta-mas-intelectuales-cristianos/ [access: 3 XII 2020].

Brague R., Le propre de l'homme. Sur une légitimité menacée, Paris: Flammarion 2013.

Brague R., Curing Mad Truths. Medieval Wisdom for the Modern Age, Notre Dame: Notre Dame UP 2019.

Chesterton G.K., The Everlasting Man, London: Hodder \& Stoughton 1927.

Chesterton G.K., Orthodoxy, London: The Bodley Head 1957.

Conferencia Episcopal Española, Memoria Anual de Actividades de la Iglesia Católica en España año 2018, Madrid: EDICE 2019, https://conferenciaepiscopal.es/wp-content/ uploads/2020/06/2020-Memoria-Actividades-Iglesia.pdf [access: 3 XII 2020].

Conferencia Episcopal Española, Memoria Anual de Actividades de la Iglesia Católica en España año 2019, Madrid: EDICE 2021, https:/www.conferenciaepiscopal.es/ wp-content/uploads/2021/05/Memoria-de-la-Iglesia-2019.pdf [access: 3 XII 2020].

Fullerton T., Walden, a game: Reflection, in M.T. Payne, N. Huntemann (eds.), How to Play Video Games, New York: New York University Press, 2019, p. 333-339.

Garrocho D., ¿Dónde están los cristianos?, https://www.elmundo.es/opinion/columnistas/2020/11/16/5fb28a36fc6c83e7528b460b.html [access: 13 XI 2020].

Guardini R., Das Wesen des Christentums, Würzburg: Werkbund 1938.

Hadjajd F., Dernières nouvelles de l'homme (et de la femme aussi), Paris: Tallandier 2017.

Haro F. de, Sobre la aportación de los cristianos, https://paginasdigital.es/sobre-la-aportacion-de-los-cristianos [access: 23 XI 2020].

Heidegger M., Phänomenologie und Theologie, in Gesamtausgabe, vol. 9, Frankfurt am Main: Vittorio Klostermann 1976, p. 45-78.

John Paul II, Saint, Catechism of the Catholic Church, London: Burns \& Oates 2006.

Juan de la Cruz, San, Obras completas, Madrid: BAC 2005.

Ministerio de Educación y Formación Profesional, Datos y cifras. Curso escolar 2019/2020, Madrid: Secretaría General Técnica 2019, https://sede.educacion.gob.es/publiventa/d/23109/19/0 [access: 3 XII 2020].

Obras Misionales Pontificias en España, Memoria de actividades 2019, Madrid: Dehon 2020, https://www.omp.es/wp-content/uploads/2020/06/MEMORIA-OMP-2019.pdf [access: 3 XII 2020].

Ortega y Gasset J., The Revolt of the Masses, New York: Norton 1957. 
Quintana Paz M.Á., ¿Dónde están (escondidos) los intelectuales cristianos?, https://theobjective.com/elsubjetivo/donde-estan-escondidos-los-intelectuales-cristianos [access: 19 XI 2020].

Torralba J.M., ¿Dónde estamos los cristianos?, https://www.elespanol.com/opinion/tribunas/20201126/cristianos/538566140_12.html [access: 26 XI 2020].

Torrijos-Castrillejo D., Historia de la filosofía moderna y contemporánea, Madrid: Ediciones Universidad San Dámaso 2017.

David Torrijos-Castrillejo - Roman Catholic priest. Teaches philosophy at the University San Dámaso of Madrid. He has published several articles and books on topics linked to the history of ancient and medieval philosophy. His main philosophical interests are philosophy of religion, metaphysics and knowledge. Some of his publications include San Alberto Magno. Introducción a la metafísica (2013), Anaxágoras y su recepción en Aristóteles (2014), Domingo Báñez. Predestinación y libertad (2021). He also translated some of Franz C. Brentano's shorter writings as well as two of his books: La Psicología de Aristóteles (2015) and La genialidad (2016). Correspondence address: dtorrijos@ sandamaso.es. 